DOI: 10.32844/2222-5374-2020-103-1.56

УДК: 347.1

Оганісян Ц. В.,

доцент кафедри цивільно-правових дисциплін

Дніпропетровського державного університету внутрішніх справ

\title{
ПРОБЛЕМИ ДОВЕДЕННЯ МОРАЛЬНОЇ ШКОДИ ЗА ЗАКОНОДАВСТВОМ УКРАЇНИ
}

В законодавстві України закріплено норми, які дають право особам на відшкодування моральної шкоди, що в сучасній концепції $\epsilon$ невід'ємною частиною захисту прав і свобод людини. Немайнова шкода - страждання, заподіяні людині внаслідок неправомірних дій відносно неї, повинна бути відшкодована в будь якому разі, тому що без цієї частини відновлення порушених прав неможливо повною мірою реалізувати принцип справедливості, адже тоді залишається некомпенсованою велика частина того негативу, якого зазнає людина. Відшкодування моральної шкоди залишається в багатьох випадках недосяжним, оскільки насамперед моральна шкода, душевні страждання, можливо деякою мірою і відображаються у висновках експертиз, але повною мірою відобразитись у них ніколи не зможуть, тому що людські почуття надто суб'єктивні. Доведення факту нанесення моральної шкоди та наявності причинно-наслідкового зв'язку $\epsilon$ дуже специфічним, тому позивачу непросто сформувати необхідну доказову базу для підтвердження наявності моральної шкоди та підтвердження причинно-наслідкового зв'язку між діями (бездіяльністю) відповідача та негативними наслідками для позивача у вигляді моральної шкоди. Кожна конкретна справа вимагає об'єктивної оцінки судом всіх обставин, оскільки судовий контроль являє собою одну з істотних гарантій захисту конституційних прав громадян, тим більше у випадках, коли фактичні обставини справи свідчать про наявність цивільно-правового спору. Мета позивача (його представника) - надати суду матеріал для такої оцінки, тобто доказову базу. Наявність достатньої доказової бази виступатиме запорукою визначення судом справедливого розміру компенсації моральної шкоди. Наголошено, що кожна конкретна справа вимагає об'єктивної оцінки судом всіх обставин, оскільки судовий контроль являє собою одну з істотних гарантій захисту конституційних прав громадян, тим більше у випадках, коли фактичні обставини справи свідчать про наявність цивільно-правового спору. Мета позивача (його представника) - надати суду матеріал для такої оцінки, тобто доказову базу. Наявність достатньої доказової бази виступатиме запорукою визначення судом справедливого розміру компенсації моральної шкоди. Зроблено висновок, що для отримання відшкодування моральної шкоди у повному обсязі необхідно використовувати всі наявні процесуальні можливості, намагатись найбільш повно і точно відобразити причинний зв'язок між порушенням прав особи і моральними стражданнями, яких вона зазнала. Не повинно виника- 
ти сумнівів щодо обсягів немайнової шкоди, і це слід підтвердити за допомогою допустимих засобів доказування.

Ключові слова: моральна шкода, відшкодування, засоби доказування, предмет доказування.

Актуальність теми. В законодавстві України закріплено норми, які дають право особам на відшкодування моральної шкоди, що в сучасній концепції є невід'ємною частиною захисту прав і свобод людини. Немайнова шкода - страждання, заподіяні людині внаслідок неправомірних дій відносно неї, повинна бути відшкодована в будь якому разі, тому що без цієї частини відновлення порушених прав неможливо повною мірою реалізувати принцип справедливості, адже тоді залишається некомпенсованою велика частина того негативу, якого зазнає людина.

Відшкодування моральної шкоди залишається в багатьох випадках недосяжним, оскільки насамперед моральна шкода, душевні страждання, можливо деякою мірою і відображаються у висновках експертиз, але повною мірою відобразитись у них ніколи не зможуть, тому що людські почуття надто суб'єктивні.

Стан дослідження. Варто зазначити, що дослідженням проблеми відшкодування моральної шкоди займались такі вітчизняні вчені, як: С. Рабінович, Д. Толкачов, М. Фролов, В. Мармазов, В. Васильєв, Л. Корчемна, В. Чернадчук, В. Паліюк, Р. Стефанчук, О. Грищук, I. Забара, Н. Павловська, О. Крикунов та ін.

Метою даного дослідження $є$ визначення особливостей визначення та доведення моральної шкоди.

Виклад основного матеріалу. Як зазначається в наукових джерелах, проблема визначення розміру моральної шкоди у вітчизняній науковій практиці виникла з моменту вступу в силу Закону України «Про внесення змін і доповнень до положень законодавчих актів України, що стосуються захисту честі, гідності та ділової репутації громадян та організацій» від 6 травня 1993 року, коли Цивільний кодекс Української РСР був доповнений статтею 440-1 про відшкодування моральної (немайнової) шкоди, адже радянське законодавство не містило ані поняття «моральна шкода», ані механізмів її відшкодування [8, с. 86].

Насамперед слід зазначити, що чинне вітчизняне законодавство не містить чіткого визначення поняття «моральна шкода». Згідно зі ст. 23 ЦК України моральна шкода полягає:

1) у фізичному болю та стражданнях, яких фізична особа зазнала у зв'язку з каліцтвом або іншим ушкодженням здоров'я;

2) у душевних стражданнях, яких фізична особа зазнала у зв'язку з протиправною

поведінкою щодо неї самої, членів її сім'ї чи близьких родичів;

3) у душевних стражданнях, яких фізична особа зазнала у зв'язку із знищенням чи пошкодженням її майна;

4) у приниженні честі та гідності фізичної особи, а також ділової репутації фізичної або юридичної особи.

На думку В. Васильєва, законодавець утримується від визначення поняття «моральна (немайнова) шкода», оскільки таке визначення, щоб 
охопити всі суттєві ознаки поняття, було б доволі громіздке: усі випадки неправомірних дій, якими може бути заподіяна моральна (немайнова) шкода, неможливо передбачити, тому моральна (немайнова) шкода може бути завдана й іншими діями, якими порушуються майнові й особисті немайнові права особи [1, с. 12].

Як слушно вказує Д. Толкачов, звертаючись до процесуальних аспектів розгляду судами загальної юрисдикції справ про відшкодування моральної (немайнової шкоди), на відміну від цивільного права у цивільному процесі термін «немайнова шкода» вже втрачає свій зміст, оскільки при зверненні до суду необхідно зазначити, в якому розмірі має бути відшкодована завдана шкода. Тобто в цьому конкретному випадку проявляється умовність поняття «немайнова шкода», яка може розцінюватися як несумісна з грошовим еквівалентом. Тому, на думку Д. Толкачова, термін «моральна шкода» більш виважений, ніж «немайнова шкода», зокрема що стосується процесуальних галузей наук та безпосередньо різних видів судочинства [5, с. 106].

0. Отраднова пропонує визначати моральну шкоду як негативні наслідки для внутрішньої, психічної сфери людини, її відчуттів, самопочуття, ментального здоров'я, що полягають у відсутності емоційного благополуччя та/або наявності психічного розладу [2, с. 21].

У своїй постанові №4 від 31 березня 1995 р. «Про судову практику в справах про відшкодування моральної (немайнової) шкоди» Пленум Верховного Суду зазначив, що суди в окремих випадках вдаються до помилок, неповно з'ясовують наявність підстав для відшкодування моральної шкоди, недостатньо обгрунтовують її розмір. Тобто сторони в процесі голослівно висували свої вимоги, а реальних доказів, які б обгрунтовували їхні вимоги - не надавали [10].

O.I. Сліпченко зазначає, що у даних категоріях справ загальний предмет доказування включає необхідність встановлення наступних умов цивільно-правової відповідальності:

- наявність моральної (немайнової) шкоди в потерпілого;

- протиправність дій особи, яка заподіяла шкоду;

- причинний зв'язок між протиправними діями та заподіяною шкодою;

- вина (у передбачених законом випадках) [4, с. 180].

Термін «страждання» означає, що дії щодо заподіювання шкоди обов'язково повинні відобразитися у свідомості потерпілої особи й викликати в неї певну психічну реакцію. Страждання важко оцінити за допомогою будь-якої методики, оскільки вони взагалі не піддаються оцінці, а втрати немайнового характеру можна визначити. Страждання викликають певні зміни в житті особи: неможливість реалізації своїх звичок і бажань, збентеженість, страх, переживання, хвилювання, емоційна нестабільність, прояви депресії, зміна артеріального тиску й виникнення інших хвороб, погіршення стосунків у колективі, у сім'ї, втрату роботи, можливості зробити кар'єру, втрату довіри близьких людей тощо; іншими словами - зменшення, знищення певного особистого немайнового блага [1, с. 12].

C.I. Шимон вказує, що для визначення глибини фізичних та душевних страждань мають значення такі критерії: 
- характер страждання (прості переживання; душевні страждання, страждання, пов'язані з фізичним болем);

- тяжкість ушкодження здоров'я (легке, середньої тяжкості, тяжке);

- вид душевних страждань (занепокоєння, нервозність, сором, приниження, страх, відчай);

- глибина страждань (незначний фізичний або душевний біль, значний біль, сильний біль, нестерпний біль, біль руйнівної для здоров'я сили) [7, с. 55].

Таким чином, найскладнішим моментом при оформленні позовної заяви про відшкодування моральної (немайнової) шкоди є збір доказів, які доводять факт спричинення моральної шкоди та розмір такої шкоди.

Формування позивачем доказової бази при поданні заяви про відшкодування матеріальної шкоди не є складним, оскільки шкода завдається або певним матеріальним об'єктам, які можуть бути оглянуті, оцінені тощо, або ж зазначається обсяг витрат позивача, які можуть бути підтверджені документально. У випадку подання позовів про компенсацію моральної (немайнової) шкоди у позивачів виникають складнощі щодо формування доказової бази [9].

Доведення факту нанесення моральної шкоди та наявності причинно-наслідкового зв'язку $є$ дуже специфічним, тому позивачу непросто сформувати необхідну доказову базу для підтвердження наявності моральної шкоди та підтвердження причинно-наслідкового зв'язку між діями (бездіяльністю) відповідача та негативними наслідками для позивача у вигляді моральної шкоди.

В більшості позовів про компенсацію моральної (немайнової) шкоди, які надходять до судів, позивачі обмежуються фразою: “Мені завдано моральної шкоди”. Однак позивачеві недостатньо заявити у позовній заяві, що він пережив або переживає моральні страждання. Цей факт має бути доведений усіма допустимими засобами доказування (показаннями свідків, довідками із медичних закладів, іншими письмовими доказами тощо) [2, с. 21].

Докази - це будь-які фактичні дані, на підставі яких суд встановлює наявність або відсутність обставин, що обгрунтовують вимоги і заперечення сторін, та інші обставини, що мають значення для правильного вирішення справи.

Ці дані встановлюються такими засобами: пояснень сторін, третіх осіб, їхніх представників, допитаних як свідків, показань свідків, письмових доказів, речових доказів, зокрема звуко- і відеозаписів, висновків експертів.

Пояснення сторін і третіх осіб надаються сторонами в цивільному процесі й фіксуються у протоколі судового засідання, а в деяких випадках - і з застосуванням технічних засобів (у таблиці, що подається нижче, цей вид доказу не розглядатиметься). Сторони, треті особи та їхні представники за їх згодою можуть бути допитані як свідки про відомі їм обставини, що мають значення для справи.

Показання свідків - це повідомлення про відомі йому обставини, які мають значення для справи. Не є доказом показання свідка, який не може назвати джерела своєї обізнаності щодо певної обставини. У справах про 
компенсацію моральної шкоди цей вид доказів $є$ найбільш поширеним. Адже зміну психологічного стану позивача в зв'язку з негативними емоційно-вольовими переживаннями можуть помітити тільки особи, які мають можливість порівняти стан позивача до події, яка спричинила переживання, та після такої події. Зважаючи на те, що явка у судовий процес $є$ для громадян неабияким психологічним випробовуванням, позивач пропонує до виклику тих осіб, які вже надали йому теоретичну згоду на виклик їх у якості свідків. Однак дійсно корисними для з'ясування обсягів спричиненої моральної шкоди є показання “незалежних" свідків - осіб, які спостерігали за позивачем "зі сторони” (наприклад, колеги по роботі, з якими позивач не підтримує тісних дружніх стосунків) або осіб, які ставляться до позивача “вимушено терпляче”, як правило, це особи, які підтримують стосунки з позивачем в силу незалежних від них обставин (наприклад, родичі одного з подружжя). На жаль, суди в більшості випадків не вживають належних заходів для залучення таких свідків.

Письмові докази - це будь-які документи, акти, довідки, листування службового або особистого характеру або витяги з них, що містять відомості про обставини, які мають значення для справи. Письмові докази у справах про компенсацію моральної шкоди, як правило, підтверджують наявність негативних наслідків, які виникли у зв'язку з перенесеними емоційно-вольовими переживаннями. Це може бути витяг з історії хвороби, лікарняний листок, письмовий висновок психолога тощо. Але відносно того, у який час ці переживання мали місце, що стало їхньою причиною, до чого вони призвели, якої вони були глибини (знову нагадаю про суб'єктивність людського переживання).

Речові докази - це предмети матеріального світу, що містять інформацію про обставини, які мають значення для справи. Речові докази у справах про компенсацію моральної шкоди не $є$ дуже поширеним видом доказів. Як речовий доказ може бути подано, наприклад, друкований засіб масової інформації, у якому надруковані відомості, що не відповідають дійсності; аудіо- або відеокасети, які містять відповідний аудіо- або відеопродукт 3 неправдивою інформацією. Найбільш поширене подання таких речових доказів, як фотографії (негативи); як правило, речові докази фігурують у справах, за якими відповідачами є засоби масової інформації.

Висновки експертів - це докладний опис проведених експертом досліджень, зроблені у результаті них висновки та обгрунтовані відповіді на питання, задані судом. Для встановлення наявності емоційних страждань можливе використання досвіду, накопиченого у психології, зокрема застосовування розроблених і впроваджених в практику комплексних методів психологічного консультування у формі психодіагностики (у тому числі і комп'ютерної) і надання різнобічної психологічної допомоги. Звертання до психологічних методик - це не тільки доцільно, але й розумно. Насправді тільки експерт-психолог може встановити наявність або відсутність ознак заподіяння особі моральної шкоди.

Досить поширеним доказом у справах про компенсацію моральної шкоди $є$ висновки експертів-медиків (крім психологів) щодо стану здоров'я позивача і обумовленості негативних емоційно-вольових переживань погіршенням стану здоров'я. 
Обгруновуючи думку щодо доцільності обов'язкового проведення судово-психологічної експертизи у справах про відшкодування моральної (немайнової) шкоди, що дозволить суду визначити адекватний розмір компенсації такої шкоди залежно від характеру завданих потерпілому фізичних та моральних страждань, Д. Толкачов наголошує на сутності судово-психологічної експертизи та висновку експерта як одного із засобів доказування у даній категорії справ. Так, Д. Толкачов підкреслює, що предметом такої експертизи є питання про особливості психіки людини, іiї реагування на екстремальні ситуації. На розгляд судово-психологічної експертизи може бути винесено питання: яким є можливий вплив тих чи інших негативних емоцій (душевних переживань), що виникли у досліджуваної особи до події, на характер її дії та стан такої особи в екстремальних умовах, проте дана експертиза не здатна дати категоричну відповідь, оскільки висновки експерта-психолога про можливість настання якоїсь події чи протікання певного процесу слід розглядати як ймовірні $[5$, c. 115].

Вище подано приблизний перелік доказів, якими можна підтвердити наявність моральної шкоди (факти, наявність подій, ставлення осіб, тобто все те, що спричинює негативні емоційно-вольові переживання позивача). При доведенні до відома суду доказів у кожному випадку треба надавати пояснення щодо причинно-наслідкового зв’язку з фактом заподіяння моральної шкоди.

Кожна конкретна справа вимагає об’єктивної оцінки судом всіх обставин, оскільки судовий контроль являє собою одну з істотних гарантій захисту конституційних прав громадян, тим більше у випадках, коли фактичні обставини справи свідчать про наявність цивільно-правового спору. Мета позивача (його представника) - надати суду матеріал для такої оцінки, тобто доказову базу. Наявність достатньої доказової бази виступатиме запорукою визначення судом справедливого розміру компенсації моральної шкоди.

Висновки. Узагальнюючи викладенене, можемо підсумувати, що для отримання відшкодування моральної шкоди у повному обсязі необхідно використовувати всі наявні процесуальні можливості, намагатись найбільш повно і точно відобразити причинний зв'язок між порушенням прав особи і моральними стражданнями, яких вона зазнала. Не повинно виникати сумнівів щодо обсягів немайнової шкоди, і це слід підтвердити за допомогою допустимих засобів доказування.

\section{СПИСОК ВИКОРИСТАНИХ ДЖЕРЕЛ}

1. Васильєв В. Окремі питання визначення поняття моральної (немайнової) шкоди. Науковий вісник Ужгородського національного університету. Серія Право. 2015. Вип. 32. С. 10-15.

2. Отраднова О. Компенсація моральної шкоди, заподіяної порушенням цивільно-правового договору. Вісник Національної Академії прокуратури України. 2015. № 2. С. 18-23.

3. Про судову практику в справах про відшкодування моральної (немайнової) шкоди : Постанова Пленуму Верховного Суду України від 31 березня 1995 № 4. URL: http://zakon4.rada.gov.ua/ laws/show/v0004700-95. 
4. Сліпченко О.I. Докази та доказування в справах про відшкодування моральної (немайнової) шкоди / Автореф. канд... юрид. наук: 12.00.03. Харків, 2011. С. 3-4.

5. Толкачов Д.І. Діяльність адвоката у справах про відшкодування моральної (немайнової) шкоди: матеріальні та процесуальні аспекти. Вісник Вищої Ради юстиції. 2011. № 2. С. 103-117.

6. Цивільний Кодекс України від 16 січня 2003 р.

7. Цивільний процес України: академічний курс: Підручник для студ. юрид. спец. вищ. навч. закл. / Ред. С.Я. Фурси. К.: Видавець Фурса С. Я.: КНТ, 2009. 848 c.

8. Шеремет Т.В., Чайка Т.С. Проблемні практичні та теоретичні аспекти відшкодування моральної шкоди згідно із законодавством України. Юридичний науковий електронний журнал. 2019. № 3. С. 85-89.

9. URL: http://www.justinian.com.ua/article.php?id=258

10. URL: http://www.yur-gazeta.com/oarticle/920/

\section{Ts. Ohanisian}

\section{PROBLEMS OF PROVING MORAL DAMAGE UNDER THE LEGISLATION OF UKRAINE}

The legislation of Ukraine enshrines norms that give individuals the right to compensation for moral damage, which in the modern concept is an integral part of the protection of human rights and freedoms. Non-pecuniary damage - the suffering caused to a person as a result of wrongful acts against him, must be compensated in any case, because without this part of the restoration of violated rights it is impossible to fully implement the principle of justice, because then remains uncompensated much of the negativity. Compensation for moral damage remains in many cases unattainable, because first of all moral damage, mental suffering, may be reflected to some extent in the conclusions of examinations, but they will never be able to fully reflect in them, because human feelings are too subjective. Proving the fact of non-pecuniary damage and the existence of a causal link is very specific, so the plaintiff is not easy to form the necessary evidence to confirm the existence of non-pecuniary damage and confirm the causal link between the actions (inaction) of the defendant and negative consequences for the plaintiff moral damage. Each case requires an objective assessment by the court of all the circumstances, as judicial review is one of the essential guarantees of protection of the constitutional rights of citizens, especially in cases where the facts of the case indicate the existence of a civil dispute. The purpose of the plaintiff (his representative) - to provide the court with material for such an assessment, ie the evidence base. The availability of sufficient evidence will be a guarantee that the court will determine the fair amount of compensation for non-pecuniary damage. It is emphasized that each case requires an objective assessment by the court of all circumstances, as judicial control is one of the essential guarantees of protection of constitutional rights of citizens, especially in cases where the facts of the case indicate a civil dispute. The purpose of the plaintiff (his representative) - to provide the court with material for such an assessment, ie the evidence base. The availability of sufficient evidence will be a guarantee that the court will determine the fair amount of compensation 
for non-pecuniary damage. It is concluded that in order to obtain compensation for non-pecuniary damage, it is necessary to use all available procedural possibilities, try to most fully and accurately reflect the causal link between the violation of individual rights and moral suffering. There should be no doubt about the amount of non-pecuniary damage, and this should be confirmed by admissible means of proof.

Keywords: moral harm, compensation, means of proof, subject of proof. 